\title{
The Strategy for the Community Participation Development in the Management of Mangrove Forest Ecosystem in Muara Gembong District, West Java
}

\author{
Kirstie Imelda Majesty ${ }^{1}$, Mahawan Karuniasa ${ }^{2}$ Herdis Herdiansyah $^{3}$ \\ \{kirstie.imelda.m@gmail.com ${ }^{1}$, mahawancac@yahoo.com ${ }^{2}$,herdis@ui.ac.id ${ }^{3}$ \} \\ School of Environmental Science, Universitas Indonesia, Jl. Salemba Raya No. 4, Jakarta, Indonesia ${ }^{1}$, School of \\ Environmental Science, Universitas Indonesia, Jl. Salemba Raya No. 4, Jakarta, Indonesia ${ }^{2}$, \\ School of Environmental Science, Universitas Indonesia, Jl. Salemba Raya No. 4, Jakarta, Indonesia ${ }^{3}$
}

\begin{abstract}
Aquatic and terrestrial ecosystems along the northern coastline of Java Island form the mangrove forests into an ecosystem rich in interacting biodiversity, one of which is in Pantai Bahagia Village in Muara Gembong District, Bekasi Regency, West Java. From year 1999 to 2014, the mangrove forests in this village continued to experience degradation; mostly due to anthropogenic factors, namely the conversion of mangrove land into ponds by coastal communities which caused coastal erosion to continue to occur in this region, the absence of wave barriers, so that seawater intrusion became high, and the tidal flood which caused enormous losses for residents who mostly had livelihoods as pond farmers. Previous researches had indicated that the mangrove conditions in Pantai Bahagia Village are categorized as severely damaged and have low biodiversity conditions, so the urgency to carry out rehabilitation is classified as high. Until 2018 community participation has begun to emerge in rehabilitating mangrove forests, but is still relatively low and has not been able to match the rate of damage. A study was conducted on 30 Pantai Bahagia villagers who have a high level of concern and participation in managing mangroves to analyze the internal and external factors, which encourage or discourage community participation and develop strategies to increase community participation in rehabilitating mangrove Pantai Bahagia Village to formulate 5 (five) alternative strategies. The proposed solutions are evaluated based on those determinants, and the rank is calculated based on the implementation criteria, namely: effectiveness, cost, duration, and sustainability using AHP as a tool in the decision-making process in solving the problems with high complexity. It is determined that the prioritized alternative to be implemented in the community of Pantai Bahagia Village in Muara Gembong District is to held capacity building like workshop and training to develop alternative livelihood \& income, as it is the most sustainable, economical, and effective alternative in encouraging the community willingness in voluntarily manage the mangrove ecosystem.
\end{abstract}

Keywords: Analytical Hierarchy Process analysis, community participation, mangrove rehabilitation, Muara Gembong District, West Java

\section{Introduction}

Mangrove systems form a crucial component of the livelihoods of coastal communities in developing countries, as they provide fish, crustaceans and other sea life for food and income; wood for fuel and energy; protection of shorelines from erosion, flooding and storm damage; and a filter for pollutants to help maintain water quality [1][2]. However, historical researches had stated that Indonesia's mangrove area have experienced rapid change in the form of degradation and loss [3]-[6] due to the increase of human activity, especially from intensive and extensive commercial aquaculture in rural livelihoods [7]. It is estimated that Java Island alone had lost $75 \%$ of its original mangrove area from 1800 to 2012 [3]. Considering the importance of the role of mangroves to protect and conserve the ecosystem components of coastal and marine areas, the sustainability management of mangrove ecosystem is absolutely necessary [8].

From a geographical point of view, Bekasi Regency is very strategic for marine trade area because it is crossed by The Pantura (North Coast Line), the primary and densest ocean route in Java Island. From year 1999 to 2014, mangrove forests in this village continued to experience degradation due to anthropogenic factors, namely: the conversion of mangrove land into ponds by coastal communities which caused coastal erosion to continue to occur in this region, the absence of wave barriers that caused seawater intrusion, and tidal flood that caused enormous losses for residents who mostly had livelihoods as pond farmers [9]-[11]. 
At present, the remaining mangrove land only reaches 379 hectares or only $13.15 \%$ of the initial coverage area. The results of prior research shown that the average shoreline change in each coastal village in Muara Gembong has decreased by 346.54 ha to 349.56 ha due to erosion and sedimentation that occurred in Muara Gembong Subdistrict from 2000 to 2012 [12]. The most severe loss was land damage the pond which has been the main livelihood of fishers in Muara Gembong. Erosion that occurred at the coast of Muara Gembong could reduce the area of the pond and could have a negative impact on the economic sector. For example, due to water pollution and abrasion, aquaculture productivity decreases from time to time, caused by flood during tide, due to the lack of mangrove belt. During West Season (Musim Barat), communities of fishermen who do not actively catch fishes started to replant mangroves for livelihood purpose [13].

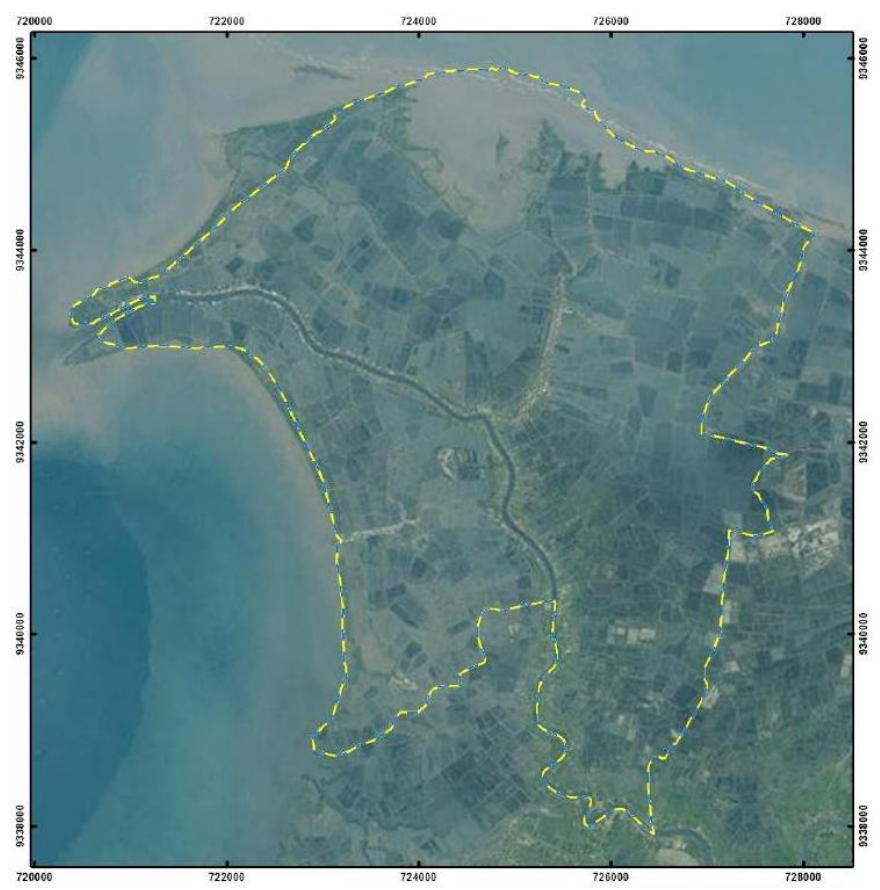

Figure 1. Muara Gembong District, Bekasi Regency, West Java

One of the factors causing the communities' low interest in managing mangroves, is that there is still a lack of alternative livelihoods apart from the aquaculture sector so that mangroves continue to experience degradation and tidal floods continue to occur, thus harming local residents. In order to ensure the function of mangrove ecosystems run well for the environment as a whole in Pantai Bahagia Village, alternative strategies are needed to be prepared to encourage the community participation in managing mangrove forest ecosystems that are effective and based on sustainable environmental management principles, which cover ecological, economic, and social aspects. Thus, in-depth interview with the community to address the core problems to generate the alternative solutions for the problem. This research aims to analyze the most implementable strategy in the development of community participation in Pantai Bahagia Village, to encourage the community participation in managing mangrove forest ecosystems with AHP as the methods.

Analytical Hierarchy Process (AHP) one of the multiple decision-making methods that model decisionmaking processes mathematically and are used to solve complex problems [14]. For this reason, the AHP method is chosen to describe the existing problem as the main objective, using selection criteria that make an activity manageable and sustainable, namely: program effectiveness (duration), duration of the program (duration), costs to be incurred during implementation program (cost), and an estimate of whether the positive impact of the program will continue or only succeed for a short period of time (sustainability).

\section{Methodology}

This research uses the combination of the in-depth interview to generate the alternative strategies and for self-judgment using the Analytical Hierarchy Process (AHP) method. The in-depth interview is conducted on 30 
productive adults (aged 17 - 60 years) living in Pantai Bahagia Village, including members of the Indonesian Mangrove Volunteer Community (KeMANGTEER), Save Muara Gembong (NGO) and Muara Beting Tourism Awareness Group (Pokdarwis), who actively participate in the management and rehabilitation of mangroves in the Pantai Bahagia Village. The in-depth interview is conducted during September to November 2018, during West Season. The population of the Pantai Bahagia villagers who have a high level of concern and participation in managing mangroves is interviewed to collect the internal and external factors, which encourage or discourage community participation and develop strategies to increase community participation in rehabilitating mangrove at Pantai Bahagia Village to formulate 5 (five) alternative strategies is conducted aimed to determine the most important factors that influence the development of pro-environmental behavior in the rural-urban community.

Next step is generating the AHP model, on which the selection criteria from the study are utilized to benchmark the offered alternative solutions. Finally, the scoring and grading are done with AHP Calculator Software, while maintaining the Consistency Ratio (CR\%) under $10 \%$. The obtained priority ranking helps to decide which solution is the best to achieve the study objective.

\section{Result and Discussion}

\subsection{Formation of Alternative Strategies}

The in-depth interview is meant to collect 24 internal and external issues faced by the adult population who are actively conserving the mangrove in Pantai Bahagia Village. The issues then are prioritized by scoring, and then 5 (five) main problems are generated based on the highest scores. The main problems are:

1. The lower income of the mangrove management community;

2. Only a few people involved in mangrove management;

3. Minimal recommendations and concern from the local government;

4. The permits and regulations are still not in line with the interests of the public, the private sector, and the government; and

5. Lower willingness and ability of the community to manage mangrove ecosystem.

Therefore, the alternative solutions are formulated by using the negation of the sentences. The alternative solutions proposed are categorized based on the socio-economics, socio-cultural, and stakeholder engagement, namely:

1. Develop the creative business as alternative income for the community (Socio-economic Alternative);

2. Involve more people from various backgrounds to commit in mangrove management, not only the fishermen community (Socio-cultural Alternative 1);

3. Engage more with the local government to get maximum recommendations and concerns (Stakeholder Engagement Alternative 1);

4. The permits and regulations comply with the interests of the public, the private sector, and the government (Stakeholder Engagement Alternative 2); and

5. Held training and workshop for the community to build their capacity in managing the mangrove ecosystem (Socio-cultural Alternative 2).

\subsection{Decision of Most Implementable Alternative Strategy}

The model of Analytical Hierarchy Process (AHP) method in determining the main objective, selection criteria, and alternative solutions for mangrove managing community in Pantai Bahagia Village area is presented in Figure 2. The main objective in this study becomes the aim of model, and the criteria and alternative solutions are generated based on literature studies. Next, each alternative will be benchmarked on priority, according to the selected criteria, thus, determining the decision that is manageable, and most important to be implemented in Muara Gembong District. 


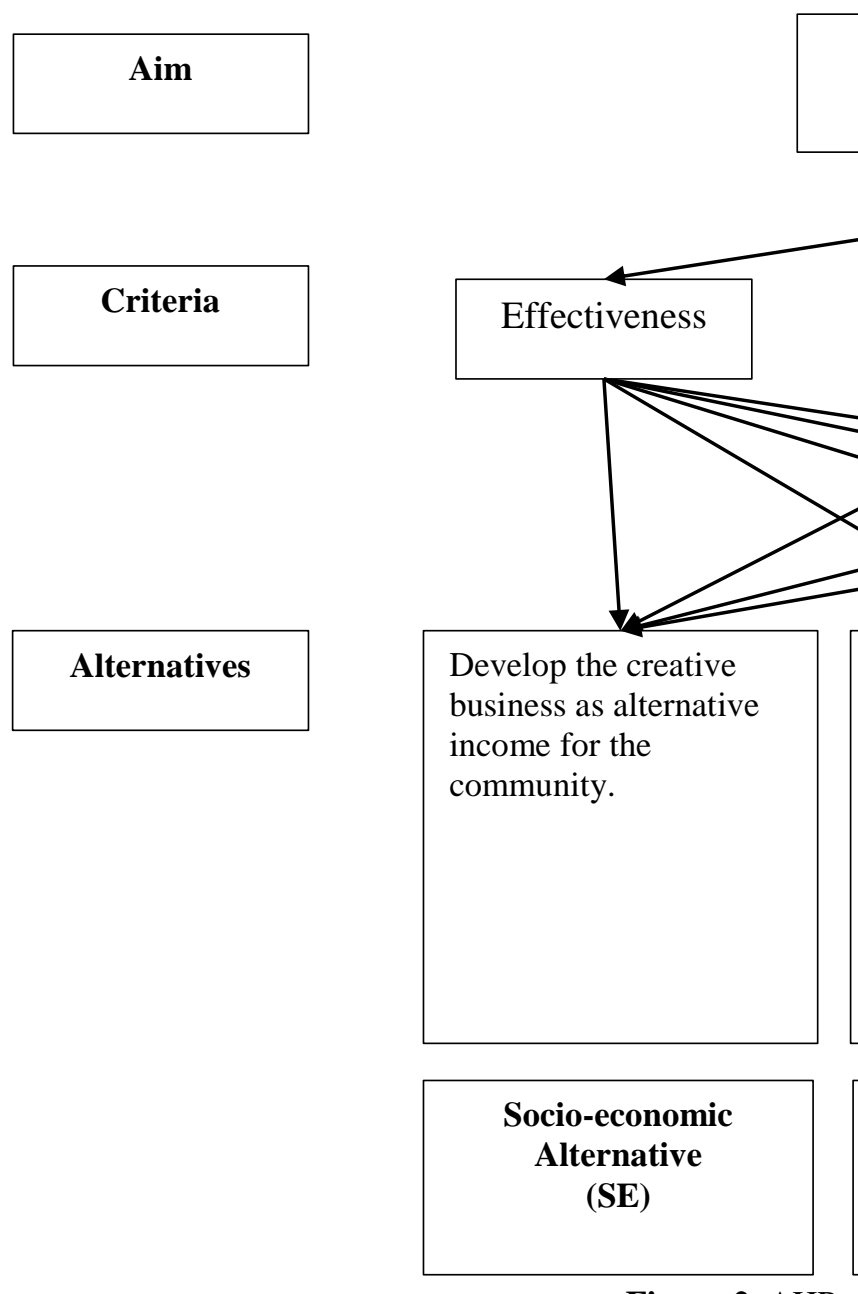

To develop community participation in the management of mangrove forest ecosystem in Pantai Bahagia Village, Muara Gembong District, West Java

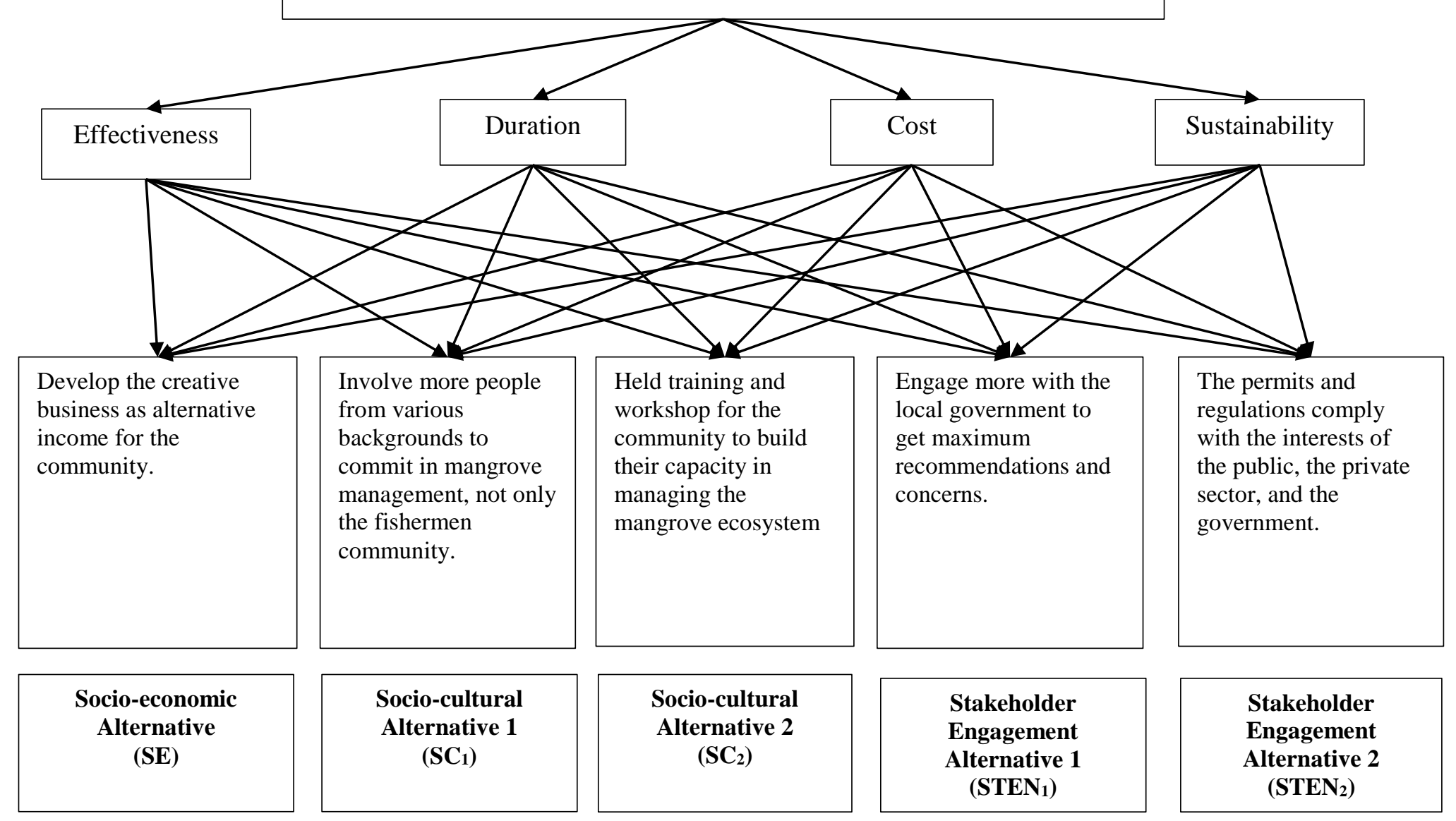

Figure 2. AHP model to determine of the main objective, selection criteria, and alternative solutions 
The considerations for criteria selection is described in Table 1.

Table 1. Consideration for Criteria Selection

\begin{tabular}{ll}
\hline CRITERIA & \multicolumn{1}{c}{ DESCRIPTION } \\
\hline Effectiveness & $\begin{array}{l}\text { The effectiveness of alternative actions is important for the } \\
\text { implementation, post-implementation and evaluation of the } \\
\text { programs. }\end{array}$ \\
Duration & $\begin{array}{l}\text { The duration of alternative actions is important to estimate which } \\
\text { program is able to be implemented the soonest. }\end{array}$ \\
Cost & $\begin{array}{l}\text { The cost of alternative actions is important to estimate which } \\
\text { program is most economical to be implemented. }\end{array}$ \\
Sustainability & $\begin{array}{l}\text { The sustainability of the alternative actions is important to decide } \\
\text { which program is sustainable, not only for cross-sectional purpose. }\end{array}$ \\
\hline
\end{tabular}

The calculation result of the priority of the criteria is presented in Table 1, where sustainability aspect of the alternative strategies becomes the first rank on priority of all 4 criteria $(=0.487)$.

Table 2. Result of AHP Calculation on Criteria Priority $(\mathrm{CR} \%=2.1 \%)$

\begin{tabular}{lccccc}
\hline & Effectiveness & Duration & Cost & Sustainability & PRIORITY \\
\hline Effectiveness & 1.00 & 7.00 & 3.00 & 0.50 & 0.331 \\
Duration & 0.14 & 1.00 & 0.50 & 0.12 & 0.056 \\
Cost & 0.33 & 2.00 & 1.00 & 0.33 & 0.126 \\
Sustainability & 2.00 & 8.00 & 3.00 & 1.00 & $\mathbf{0 . 4 8 7}$ \\
\hline TOTAL & & & & $\mathbf{1 . 0 0 0}$ \\
\hline
\end{tabular}

Based from the calculation, sequentially ranked criteria from the first to last priority are: sustainability, effectiveness, cost, and then duration. This ranking method is accepted due to as the purpose of the program is to ensure the program implementation is not only sustainable, but also effective and cost-friendly. The duration is not important as it is understandable that mangrove saplings need time to grow into its mature form. Thus, all of these activities are not beneficial if they are only done once (cross-sectional). Hence, if restoration of mangrove becomes habitual and conducted in daily activities, the result can be obtained in long term.

Table $3-6$ presented the results of pairwise comparison result of each alternative activity explained in Figure 2, following the other of the criteria ranking. Table 3, 5, and 6 indicate that the pairwise comparison ranked the Alternative of Socio-economic as the first rank; while Table 4 shows that the Alternative of Socio-cultural is the first rank. Afterwards, each value grade on priority is calculated to get the value of total priority, thus, resulted in the ranking of alternative solutions as presented in Table 7, where Socio-economic alternative placed on the first rank with priority of $0.456(45.6 \%)$. 
Table 3. Result of AHP Calculation on Priority Towards Sustainability (CR\% $=3.3 \%$ )

\begin{tabular}{lcccccc}
\hline & SE & SC $_{1}$ & SC $_{2}$ & STEN $_{1}$ & STEN $_{2}$ & Priority \\
\hline SE & 1.00 & 6.00 & 1.00 & 8.00 & 9.00 & 0.438 \\
SC $_{1}$ & 0.17 & 1.00 & 0.33 & 5.00 & 2.00 & 0.115 \\
SC $_{2}$ & 1.00 & 3.00 & 1.00 & 9.00 & 7.00 & 0.357 \\
STEN $_{1}$ & 0.12 & 0.20 & 0.11 & 1.00 & 0.50 & 0.035 \\
STEN $_{2}$ & 0.11 & 0.50 & 0.14 & 2.00 & 1.00 & 0.055 \\
\hline TOTAL & & & & & & $\mathbf{1 . 0 0 0}$ \\
\hline
\end{tabular}

Table 4. Result of AHP Calculation on Priority Towards Effectiveness (CR\% $=3.4 \%$ )

\begin{tabular}{lcccccc}
\hline & SE & SC $_{1}$ & SC $_{2}$ & STEN $_{1}$ & STEN $_{2}$ & Priority \\
\hline SE & 1.00 & 0.33 & 3.00 & 6.00 & 8.00 & 0.290 \\
SC $_{1}$ & 3.00 & 1.00 & 3.00 & 7.00 & 9.00 & 0.485 \\
SC $_{2}$ & 0.33 & 0.33 & 1.00 & 2.00 & 4.00 & 0.127 \\
STEN $_{1}$ & 0.17 & 0.14 & 0.50 & 1.00 & 2.00 & 0.061 \\
STEN $_{2}$ & 0.12 & 0.11 & 0.25 & 0.50 & 1.00 & 0.037 \\
\hline TOTAL & & & & & & $\mathbf{1 . 0 0 0}$ \\
\hline
\end{tabular}

Table 5. Result of AHP Calculation on Priority Towards Cost $(\mathrm{CR} \%=3.2 \%)$

\begin{tabular}{lcccccc}
\hline & SE & SC $_{1}$ & SC $_{2}$ & STEN $_{1}$ & STEN $_{2}$ & Priority \\
\hline SE & 1.00 & 6.00 & 2.00 & 7.00 & 7.00 & 0.499 \\
SC $_{1}$ & 0.17 & 1.00 & 0.50 & 3.00 & 1.00 & 0.104 \\
SC $_{2}$ & 0.50 & 2.00 & 1.00 & 7.00 & 4.00 & 0.266 \\
STEN $_{1}$ & 0.14 & 0.33 & 0.14 & 1.00 & 0.33 & 0.041 \\
STEN $_{2}$ & 0.14 & 1.00 & 0.25 & 3.00 & 1.00 & 0.890 \\
\hline TOTAL & & & & & & $\mathbf{1 . 0 0 0}$
\end{tabular}

Table 6. Result of AHP Calculation on Priority Towards Duration $(\mathrm{CR} \%=3.4 \%)$

\begin{tabular}{lcccccc}
\hline & SE & SC $_{1}$ & SC $_{2}$ & STEN $_{1}$ & STEN $_{2}$ & Priority \\
\hline SE & 1.00 & 8.00 & 4.00 & 7.00 & 9.00 & 0.597 \\
SC $_{1}$ & 0.12 & 1.00 & 0.50 & 2.00 & 2.00 & 0.097 \\
SC $_{2}$ & 0.25 & 2.00 & 1.00 & 5.00 & 3.00 & 0.190 \\
STEN $_{1}$ & 0.14 & 0.50 & 0.20 & 1.00 & 0.50 & 0.049 \\
STEN $_{2}$ & 0.11 & 0.50 & 0.33 & 2.00 & 1.00 & 0.067 \\
\hline TOTAL & & & & & & $\mathbf{1 . 0 0 0}$ \\
\hline
\end{tabular}

Table 7. Result of AHP Calculation on Total Priority

\begin{tabular}{lcc}
\hline & Priority & Rank \\
\hline Socio-economic Alternative & 0.456 & 1 \\
Socio-cultural Alternative 1 & 0.200 & 4 \\
Socio-cultural Alternative 2 & 0.235 & 3 \\
Stakeholder Engagement Alternative 1 & 0.047 & 5 \\
Stakeholder Engagement Alternative 2 & 0.262 & 2 \\
\hline
\end{tabular}




\section{Conclusions}

Based on the AHP Analysis, it is determined that Alternative Socio-economical, the development of the creative business as alternative income for the community, is the chosen strategy as the most sustainable, effective, economical, and the fastest alternative strategy to develop community participation in the management of mangrove forest ecosystem in Pantai Bahagia Village, Muara Gembong District, West Java. It is recommended for all stakeholders to collaborate to formulate a business plan for the fishermen community, such as ecotourism, mangrove planting activity with third parties where the tourists pay for the young trees, art, and/or traditional culinary as side income from aquaculture business, so that the mangrove deforestation will be reduced.

Acknowledgments. The authors would like to thank Universitas Indonesia for support our research under grand scheme Hibah Publikasi Internasional Terindeks untuk Tugas Akhir Mahasiswa (Hibah PITTA) Research Grant Contract No. 2581/UN2.R3.1/HKP.05.00/2018.

\section{References}

[1] S. E. Orchard, L. C. Stringer, and C. H. Quinn, "Impacts of aquaculture on social networks in the mangrove systems of northern Vietnam," Ocean Coast. Manag., vol. 114, no. September, pp. 1-10, 2015.

[2] Karimah, "Peran Ekosistem Hutan Mangrove Sebagai Habitat Untuk Organisme Laut," J. Biol. Trop., vol. 17, no. 2, pp. 51-58, 2017.

[3] M. Ilman, P. Dargusch, P. Dart, and Onrizal, "A historical analysis of the drivers of loss and degradation of Indonesia's mangroves," Land use policy, vol. 54, pp. 448-459, 2016.

[4] B. Hamuna, A. N. Sari, and R. Megawati, "Kondisi Hutan Mangrove di Kawasan Taman Wisata Alam Teluk Youtefa, Kota Jayapura," Maj. Ilm. Biol. Biosf. A Sci. J., vol. 35, no. 2, pp. 75-83, 2018.

[5] Sodikin, "Kerusakan Mangrove Serta Korelasinya Terhadap Tingkat Intrusi Air Laut (Studi Kasus Di Desa Pantai Bahagia Kecamatan Muara Gembong Kabupaten Bekasi)," Universitas Diponegoro, 2013.

[6] N. Suwargana, "Analisis Perubahan Hutan Mangrove Menggunakan Data Penginderaan Jauh Di Pantai Bahagia, Muara Gembong, Bekasi," J. Penginderaan Jauh, vol. 5, pp. 64-74, 2008.

[7] E. Damastuti and R. De Groot, "Effectiveness of community-based mangrove management for sustainable resource use and livelihood support: A case study of four villages in Central Java , Indonesia," J. Environ. Manage., vol. 203, pp. 510 521, 2017.

[8] F. Fatimatuzzahroh, S. P. Hadi, and H. Purnaweni, "Mangrove Cultivation Community Based in Karangsong, Indramayu, West Java," IOP Conf. Ser. Earth Environ. Sci., vol. 145, no. 1, 2018.

[9] I. Erawati and Mussadun, "Partisipasi Masyarakat dalam Pengelolaan Sumber Daya Lingkungan Mangrove di Desa Bedono, Kecamatan Sayung", Ruang: Jurnal Perencanaan Wilayah dan Kota, vol. 1, pp. 31-40, 2013. [Accessed 11 July 2019].

[10]E. Prayudha, B. Sulardiono, and B. Hendrarto, "Strategi Kelompok Pantai Lestari Dalam Pengembangan Kegiatan Rehabilitasi Mangrove Di Desa Karangsong 
Kabupaten Indramayu. Diponegoro", Journal Of Maquares - Management Of Aquatic Resource, vol. 3, no. 3, pp. 80-87, 2014. [Accessed 11 July 2019].

[11] Sodikin, "Analisis Abrasi Dengan Menggunakan Teknologi Penginderaan Jauh (Studi Kasus di Desa Pantai Bahagia Kecamatan Muara Gembong Kabupaten Bekasi)", Jurnal Seminar Nasional Geomatika, vol. 2016, pp. 1-8, 2016. [Accessed 11 July 2019].

[12] D. Ekaputri, W. Windupranata and A. Harto, "The Calculation of Erosion and Sedimentation Rate in Coastal Zone Using Satellite Imageries (Case Study: Kecamatan Muara Gembong, Kabupaten Bekasi, West Java)", Indonesian Journal of Geospatial, vol. 2, no. 3, pp. 17-33, 2014. Available: http://journals.itb.ac.id/index.php/ijog/article/view/2165/1105. [Accessed 11 July 2019].

[13] K. Majesty and M. Fadmastuti, "Degree of community participation in mangrove resources management as livelihood support in West Java, Indonesia", E3S Web of Conferences, vol. 74, p. 10005, 2018. Available: 10.1051/e3sconf/20187410005 [Accessed 11 July 2019].

[14] M. Şahin And H. Yurdugül, "A Content Analysis Study on the Use of Analytic Hierarchy Process in Educational Studies", Eğitimde ve Psikolojide Ölçme ve Değerlendirme Dergisi, pp. 376-392, 2018. Available: 10.21031/epod.373784 